\title{
Editorial
}

\section{Una esperançada consolidació}

El moment més emocionant en la vida d'una revista és sens dubte l'aparició del seu primer número. És l'instant en què la idea inicial i tots els esforços que l'han seguida es veuen plasmats en una nova capçalera, amb la seva portada, els seus primers articles, etc.

En general, en el marc actual de la nostra societat, els segons, especialment en els àmbits molt marcats per la competitivitat — però quins no ho estan?-, no tenen ni de bon tros l'aurèola dels primers, i fins i tot han de patir una certa percepció de fracàs. No és el cas, tanmateix, quan parlem d'una revista. El segon número no és, certament, la prova de la consolidació del projecte, però si més no nés la primera esperançada passa i la constatació que la iniciativa i el projecte no nasqueren d'una pruija poc o gens fonamentada, sinó que s'assenten en unes bases prou sòlides.

Aquestes bases descansen principalment a pensar la proposta de la revista Arxiu d'Etnografia de Catalunya com una eina al servei d'uns col-lectius concrets amb una finalitat precisa. La pressió per publicar sembla haver assolit avui llindars gairebé de colllapse. Així les coses, de forma paradoxal, en l'era de les més grans facilitats per trobar l'aixopluc de qualsevol text en la illimitada galàxia virtual, es fa en canvi més i més difícil poder aconseguir publicar un text de caire acadèmic en una revista d'aquestes característiques, bé sigui en paper o de manera virtual. Les persones més negativament afectades per aquesta situació, òbviament, són aquelles que s'inicien en el món de la publicació de treballs de recerca, els estudiants i les estudiants de postgrau.

Per aquesta raó, fonamentalment, vam pensar que la segona etapa d'aquesta revista no implicava reinventar-se davant l'espectacularitat dels canvis ocorreguts des de la seva inicial aparició trenta anys enrere perquè l'objectiu, sorprenentment, podia i havia de continuar sent el mateix: donar l'oportunitat als nostres estudiants que fan les seves primeres passes en el camí de la recerca de confegir un article i publicar-lo. Això, juntament amb la invitació al pro- 
fessorat del DAFITS perquè informi dels diferents projectes de recerca en curs, així com amb la reserva d'un espai per comentar i analitzar algunes de les publicacions fetes per membres del DAFITS i la demanda de colllaboració a professors visitants habituals de casa nostra, permeten elaborar una publicació que és un aparador privilegiat dels nuclis de recerca del grup d'antropologia de Tarragona, de les seves temàtiques, dels nous valors emergents, de les diferents metodologies d'abordatge i perspectives teòriques usades i, en definitiva, del compromís de totes aquestes persones plegades per difondre allò que fem.

Aquest esperançador número 2 - no podia ser d'una altra manera- és un compendi admirable de tot el que acabo d'assenyalar. Els articles estan signats per vuit estudiants dels diferents ensenyaments de postgrau del DAFITS, sis noies i dos nois, sobre un ventall de temàtiques facilment integrades sota les etiquetes de l'antropologia urbana, l'antropologia mèdica, la immigració o els estudis de joventut. Es tracta, en un bon nombre d'ocasions, d'articles primigenis i, tanmateix, el lector podrà observar que són textos d'una solidesa i maduresa apreciables. Textos que, d'altra banda, tenen la virtut de mostrar, també, la vitalitat, la diversitat i la innovació que aquest modest enclavament de l'antropologia tarragonina és capaç de produir i transmetre a la comunitat científica a través d'aquest renovat i persistent alhora Arxiu d'Etnografia de Catalunya.

Jordi Roca Girona

Director del Departament d'Antropologia, Filosofia i Treball Social Universitat Rovira i Virgili 